\title{
4. Selected Asian countries and the food supply chain (between food security and food safety)
}

\section{Bruna Zolin}

\section{INTRODUCTION}

The world's population is suffering from a huge paradox: the coexistence of obesity and malnutrition. According to the World Health Organization (WHO, 2014), 39 per cent of adults aged 18+ were overweight $\left(B M I^{1} \geq 25 \mathrm{~kg} / \mathrm{m}^{2}\right.$ ) (39 per cent of men and 40 per cent of women) and 13 per cent were obese $\left(\mathrm{BMI} \geq 30 \mathrm{~kg} / \mathrm{m}^{2}\right)(11$ per cent of men and 15 per cent of women) in 2014. Thus, nearly two billion adults worldwide are overweight and, of these, more than half a billion are obese. The prevalence of overweight and obese people was highest in the regions of the Americas (61 per cent overweight in both sexes, and 27 per cent obese) and lowest in the Southeast Asia region (22 per cent overweight in both sexes and 5 per cent obese). In the American, European and eastern Mediterranean regions over 50 per cent of women were overweight. In all three of these regions, roughly half of overweight women were obese ( 25 per cent in Europe, 24 per cent in the eastern Mediterranean and 30 per cent in the Americas). In the African, eastern Mediterranean and Southeast Asian regions, women had roughly double the obesity prevalence of men. On the other hand, about 805 million people (11.3 per cent of the world's population) were estimated to be chronically undernourished in 2012 (FAO, 2014b) with marked differences across regions. SubSaharan Africa has the highest prevalence of undernourishment, with only modest progress in recent years in alleviating this. Around one in four people in the region remains undernourished. Asia, the most populous region in the world, still has the highest number of undernourished people.

The issue of emerging Asia, where there has been a gradual increase in income per capita and in population, especially in those countries where rice is the most important food, food security and food safety can become 
an impediment to growth. With increasing urbanization, the need for processed foods has accentuated the importance of the food industry that is not always sufficiently widespread and efficiently managed. Against this background, the aim of this chapter is to describe the field of food and beverages in the selected Asian countries, comparing it, where appropriate, with the European field, and highlighting future trends. The chapter is divided into several sections. Starting with a brief description of the food supply chain in section 2 , it goes on to analyse the dynamics of food supply in kilocalories per capita terms and describes the strong duality that exists within the sector in section 3. Section 4 describes in more detail the food sector in the selected Asian countries. Some synthetic considerations conclude the chapter.

\section{FOOD SUPPLY CHAIN: OVERVIEW}

Many factors have influenced and are influencing the food supply chain in the world economy, but the food supply chain is a complex issue because it is composed of a diverse range of companies operating in different markets and selling varied food products to meet the tastes and demands of different customers. The food supply chain connects three economically important sectors: the agricultural sector, the food processing industry and the distribution sector (wholesale and retail). The food supply chain plays a substantial role in all countries of the world because it must satisfy the basic need of the population. Food needs and diets evolve over time, being influenced by many factors and complex interactions. Income levels and income distribution, prices, individual preferences, cultural traditions, as well as geographical, environmental, social and economic factors all interact in a complex manner to shape dietary consumption patterns. If food security ${ }^{2}$ is the requirement to provide the amount of food needed to satisfy the food needs of the world population, food safety encompasses actions aimed at ensuring that all food is as safe as possible. Food safety policies and actions need to cover the entire food chain, from production to consumption. Thus, the sector can offer great opportunities to the food industry in terms of food value-added and differentiation, real or perceived, by consumers. Since the early 1990s, mainly population growth but also income growth and urbanization have driven the growth in demand for food in developing countries, but in parallel, a demand for products with higher quality at reasonable prices has been created. According to the UN Food and Agriculture Organization (FAO), with income growth, food demand has gradually shifted from a vegetable diet to a higher content of animal protein diet (FAO, 2012, 2015). Agribusiness companies, in this 
Table 4.1 Per capita food supply

\begin{tabular}{lcccc}
\hline Country & \multicolumn{4}{c}{$\begin{array}{c}\text { Quantity } \\
\text { (kcal/capita/day) }\end{array}$} \\
\cline { 2 - 5 } & 1996 & 2001 & 2006 & 2011 \\
\hline China & 2703 & 2819 & 2883 & 3074 \\
India & 2343 & 2331 & 2331 & 2459 \\
Indonesia & 2548 & 2484 & 2484 & 2713 \\
Japan & 2963 & 2890 & 2777 & 2719 \\
Malaysia & 2924 & 2822 & 2816 & 2855 \\
Philippines & 2364 & 2374 & 2516 & 2608 \\
Singapore & n.a. & n.a. & n.a. & n.a. \\
South Korea & 3060 & 3080 & 3121 & 3329 \\
Thailand & 2563 & 2578 & 2795 & 2757 \\
Vietnam & 2018 & 2298 & 2482 & 2703 \\
EU of which & & & & \\
Germany & 3297 & 3363 & 3463 & 3539 \\
France & 3519 & 3640 & 3513 & 3524 \\
Italy & 3558 & 3674 & 3610 & 3539 \\
Spain & 3360 & 3366 & 3278 & 3183 \\
\hline
\end{tabular}

Source: FAO (2014a).

way, gained more power, increasing the value-added of processed food. Exporting companies in developing countries have also benefited from a global demand for exotic products from developed countries, which constitute a niche market with a rather inelastic demand curve, in respect of prices. The introduction of standardization for food products is growing in importance, changing the way the world trades, and is driven by consumers, more and more alert and aware, willing to buy, even at higher prices, products with specific properties or obtained with sustainable production processes. It is very difficult to assess the value generated by the food supply chain because food or drink may be considered at the same time as a commodity and as an ingredient (such as meal), and its value should be calculated at each stage of production and processing. However, some information is available to better understand the size and the relevance of the sector. As far as food quantity is concerned, the most widely used data on food supply and consumption is published by the FAO (FAO, 2014a). Food supply expressed in kilocalories (kcal) per capita per day is a key variable used for measuring the evolution of the global and regional food situation. Table 4.1 shows that food supply has been almost constant 
in European countries while it has been rising rapidly in some Asian countries.

From an economic and social point of view, according to the International Labour Organization of the United Nations (ILO, 2012), in 2008 the food and beverage $(\mathrm{F} \& \mathrm{~B})$ industry employed 22 million people in the world. Women represent 40 per cent of the total. In some sub-sectors such as fish processing and the processing of fruits and vegetables, women make up the majority of the workforce. The world food and beverage sector, which comprises farming, food production, distribution, retail and catering, has surpassed US\$5.7 trillion since 2009. According to the Food and Beverage Industry Global Report (IMAP, 2010), Europe accounts for the largest share in the global F\&B industry and Asia-Pacific is emerging as a major contributor of raw materials. China, Russia and India have increased their production capacities. During 2003-2007 China increased its wheat production capacity by 26 per cent, while Russia raised its capacity by 45 per cent. Over the same period, wheat production in the United States decreased by 12.5 per cent. In 2009, roughly 58 per cent of produced food was consumed by developing countries (the majority of the increase in global population from 6.6 billion in 2008 to 9 billion in 2050 is expected to come from developing countries) and it is expected the ratio will climb to 72 per cent by 2050 based on current population projections. Approximately 37 per cent of the world's population lives in China and India in 2015. Packaged food forms the majority of total food consumed, with developed countries (namely the United States, Japan and the EU) accounting for more than half of global sales of packaged products, while raw products, which need to be processed before becoming edible, account for a large proportion of retail sales in developing countries. However, with rising income levels, consumption in developing countries is also shifting towards packaged food products. The United States, Italy, Peru, Germany, Australia and India are some of the top countries exporting processed food and beverages. The United States, Germany, France, Australia and Switzerland are some of the leading exporters of food processing equipment. Saudi Arabia, Asia, Africa, Russia, China and South America are some of the leading countries and regions that import processed food and beverages. Moreover, in the EU in 2012, the food and beverage sector is, in terms of employment and turnover, the most important contributor to the manufacturing sector (European Commission, 2015). ${ }^{3}$ Even in the United States, the industry is a crucial sector for the economy as it employs a large number of workers, about 1.5 million people (USDA, 2013). Lastly, the number of large retail stores, both in developed and in developing countries, has grown exponentially. With their global spread, they can promote products differentiated by their nature, origin and processes. Small to 
medium retail stores in local areas coexist with large companies, and, generally, offer local food based on seasonal production.

\section{DUALISM IN THE F\&B INDUSTRIAL SECTOR}

A strong dualism characterizes the F\&B sector. On the one hand, a few very large multinational companies, widely distributed in the world and with a strong bargaining power, are able to meet a significant percentage of the world's food needs. On the other hand, many small businesses operate locally with a geographically limited range of action. Oxfam's 'Behind the Brands' report estimated that worldwide in the food and drink sector, there are about 1.5 billion producers, of which no more than 500 companies control 70 per cent of food choices, satisfying the needs of about 7 billion people (Oxfam, 2013). Within these, a very small group plays an oligopolistic role. According to Oxfam the ten top F\&B multinational companies are:

1. Associated British Food (ABF), a British multinational food processing and retailing company whose headquarters are in London. It is the world's second-largest producer of both sugar and baker's yeast and a major producer of other ingredients (emulsifiers, enzymes and lactose). The grocery division is a major manufacturer of both branded and private label grocery products. The key brands are Askeys, Billington's, Blue Dragon, Crusha, Jacksons of Piccadilly, Jordans, La Tisaniere and Patak's. In the future, it is going to expand sugar operations in Africa, bio-ethanol production in the United Kingdom and yeast/yeast extract production in China.

2. The Coca-Cola Company is one of the largest manufacturers and distributors of soft drinks and concentrate syrups worldwide, better known by the name of its original product, Coca-Cola. The headquarters is located in Atlanta (Georgia). The key brands are Powerade, Minute Maid, Coca-Cola, Fanta and Sprite. Future plans are to cater to the growing non-alcoholic, ready-to-drink and water markets.

3. Danone is a France-based food company that primarily produces fresh milk products, baby foods, biscuits, cereal products and medical nutrition products. It also co-produces bottled water (Evian). The key brands are Activia, Danette, Nutricia and Evian. Future plans are linked to concentration on the promotion of health through food products to as many people as possible. 
4. General Mills is an American multinational manufacturer and marketer of branded consumer foods sold through retail stores. Its headquarters is in Minneapolis. The company markets many well-known North American brands. The main products sold are: bread, cereals, fruit snacks and ice cream. The key brands are Flavor Wave, Fruit Brute, General Mills, Frosted Cheerios, Cheddar Classics, Bake Shop and Better for Bread. Future plans are for the introduction of new products and extending existing brands to new markets.

5. Kellogg's is an American multinational food manufacturing company headquartered in Michigan. Kellogg's produces cereal and convenience foods, including cookies, crackers, toaster pastries, cereal bars, fruitflavoured snacks, frozen waffles, and vegetarian foods. Key brands are Kellogg's, Crunch, Murray, Honey Smacks, Fruit Harvest and Froot Loops. The future strategy is entry into the natural foods segment.

6. Mars is a US family-owned company in the chocolate and confectionery space. The headquarters is located in Virginia. It is known primarily for confectionery products, and its key brands include M\&M's, Snickers, Orbit, Extra, Uncle Bens, Flavia, Galaxy, Milky Way and Twix.

7. Mondelez International (previously Kraft Foods) is a US multinational company operating in the food sector. The company is the brand owner of food and snacks, which previously fell under the brand Kraft Foods (the corporation decided to keep the brand Kraft Foods for North America only). The key brands are: Easy Cheese, Pepito, Toasted Chips, Toblerone, Twist, Splendid, Jacob's and Honey Maid. The future strategy is to boost higher-quality organic revenue growth.

8. Nestlé, based in Switzerland, is a large multinational company operating in the nutrition, health and wellness sectors. Nine categories divide products: prepared dishes and cooking aids, beverages, confectionery, ice cream, water, pet care, milk products, nutrition, and pharmaceuticals. The key brands are Nescafé, Maggi, Milo, Kit Kat, Gloria, Nestlé and Power Bar. For the future, it intends to increase its presence in the out-of-home market by doubling Nestlé Professional's sales over the next ten years and focusing on developing and emerging markets.

9. PepsiCo Incorporated (in short, Pepsi Company) is a US multinational active in the production, marketing and sale of a wide variety of drinks, both carbonated and non-carbonated, but also of food, such as snacks. The key brands are Pepsi, Diet Pepsi, Mirinda, Mountain Dew and Chips \& Chunks. The future programmes are to expand businesses in key emerging markets. 
Table 4.2 Top 50 global food and beverage companies per region (2010)

\begin{tabular}{lccccc}
\hline & Europe & US and Canada & South America & \multicolumn{2}{c}{ Asia } \\
\cline { 4 - 6 } & & & & Total & Japan \\
\hline Number & 15 & 20 & 8 & 7 & 6 \\
$\%$ of total & 30 & 40 & 16 & 14 & $86^{*}$ \\
\hline
\end{tabular}

Note: * Percent of Asian total.

Source: IMAP (2010).

Table 4.3 Top 50 global food and beverages companies: market shares (percent of total) (2010)

\begin{tabular}{cccccc}
\hline Europe & Americas & Canada & Asia & Oceania & Africa \\
\hline 22.2 & 46.7 & 5.5 & 19.4 & 2.4 & 3.9 \\
\hline
\end{tabular}

Source: Author's elaboration on IMAP (2010).

10. Unilever is a British-Dutch multinational consumer goods company co-headquartered in the Netherlands and the United Kingdom. Products include food beverages, cleaning agents and personal care products. Key brands are Lipton and Knorr. The future strategy is improved market development in developing and emerging markets.

Expanding the range of analysis to the top 50 companies in the food and beverage sector, according to IMAP (IMAP, 2010), businesses located in the United States and in Canada are the most numerous, followed by those in Europe and South America (Table 4.2). The Asian continent is in fourth place, achieved thanks to the high number of Japanese companies. In terms of market share, the Americas account for almost 50 per cent of the world total (Table 4.3).

In addition, the sector is involved in a large number of mergers and acquisitions. In terms of continents, first place, according to rankings compiled in 2009, is occupied (according to the number of transactions) by Europe and, in terms of value, by Asia. If the analysis is made comparing countries, the most active are the United States (in terms of number and value), followed by Brazil and Australia. Among the Asian countries, the Philippines occupies fourth place (Table 4.4).

In 2010, according to the classification of the top ten grocery markets 
Table 4.4 Transactions in the $F \& B$ sector in the top five countries and continents by value (2009)

\begin{tabular}{lcc}
\hline Top 5 countries & Number of transactions & $\begin{array}{c}\text { Value } \\
\text { (USD mn) }\end{array}$ \\
\hline United States & 174 & 7475 \\
Brazil & 15 & 7089 \\
Australia & 29 & 6079 \\
Philippines & 6 & 4230 \\
Belgium & 13 & 3558 \\
\hline Top 5 continents & Number of & Value \\
& transactions & (USD mn) \\
\hline Asia & 183 & 11127 \\
Europe & 520 & 9182 \\
North America & 197 & 8027 \\
South America & 34 & 7785 \\
Oceania & 44 & 6145 \\
\hline
\end{tabular}

Source: Author's elaboration on IMAP (2010).

Table 4.5 Top ten grocery markets by value

\begin{tabular}{|c|c|c|c|c|c|}
\hline \multicolumn{3}{|c|}{2010} & \multicolumn{3}{|c|}{$2014 *$} \\
\hline Rank & Country & $€$ (billions) & Rank & Country & $€$ (billions) \\
\hline 1 & US & 638 & 1 & China & 761 \\
\hline 2 & China & 529 & 2 & US & 745 \\
\hline 3 & Japan & 345 & 3 & India & 448 \\
\hline 4 & India & 279 & 4 & Japan & 360 \\
\hline 5 & France & 205 & 5 & Russia & 322 \\
\hline 6 & Russia & 186 & 6 & Brazil & 284 \\
\hline 7 & Brazil & 185 & 7 & France & 228 \\
\hline 8 & UK & 170 & 8 & UK & 198 \\
\hline 9 & Germany & 160 & 9 & Germany & 168 \\
\hline 10 & Italy & 130 & 10 & Indonesia & 167 \\
\hline
\end{tabular}

Note: * 2014 is calculated using fixed exchange rates based on the average rates of 2009 from www.oanda.com.

Source: Author's elaboration on IMAP (2010). 
by value (Table 4.5), China, Japan and India are respectively second, third and fourth. In 2014, China exceeded the United States and was ranked first. It is worth pointing out, again in 2014, the exit of Italy and the entry of Indonesia among the top ten grocery markets.

\subsection{The EU}

The prevalence of small businesses from agriculture to retail characterizes the European supply chain. The agricultural sector of the EU28, in 2010, is composed of about 12.2 million farms, involving a surface area of 174.1 million hectares $^{4}$ (approximately 40 per cent of the total EU). The average size of each agricultural holding (farm) is 14.2 hectares. There are substantial farm size differences across member states, regions and types of farming. A large number (6 million or half of all holdings) consists of very small farms (less than two hectares in size) that occupy a small proportion ( 2.5 per cent) of the total land area and a small number of holdings (2.7 per cent) of very large farms (more than 100 hectares) covers almost half (50.2 per cent) of the arable land in the EU28. Of the 12.2 million agricultural holdings in the EU28 in 2010, 5.5 million holdings (44.6 per cent) have a standard output less than EUR2000 per annum and contribute to forming only 1.4 per cent of total agricultural economic output. By contrast, the 1.9 per cent of holdings with an output higher than EUR250000 accounted for almost one half (47.8 per cent) of all agricultural economic output (European Commission, 2013a). The sector is highly supported the Common Agricultural Policy (CAP) is one of the oldest policies of the EU. The CAP has been modified on many occasions. The reforms gradually moved from a production-oriented policy to a market-oriented vision. In particular, the 2003 reform introduced the Single Payment Scheme (SPS) or the Single Farm Payment (SFP). The new scheme was introduced to change the way the EU supported its farming sector by removing the link between subsidies and production. This reform focused on consumers and taxpayers, while giving farmers the freedom to produce what the market wanted $^{5}$ (European Commission, 2013b). The food and drink industry sector is one of the largest and most important manufacturing sectors in Europe. In 2011 Europe's food market was made up of about 287000 companies and 4.25 million employees (15 per cent of direct employment in the EU manufacturing sector). France, Italy, Spain and the United Kingdom accounted for 70 per cent of the turnover for the EU27, whereas the twelve new member states accounted for only 8.7 per cent. A large part of the food and drink companies are small and medium-sized enterprises (SMEs) (accounting for 49.3 per cent of the food and drink turnover and 63.4 per cent of food and drink employment). In the food and drink sector, 
Table 4.6 Number of SMEs and large companies by sub-sector (2011)

\begin{tabular}{lcc}
\hline & $\begin{array}{c}\text { SMEs } \\
(\%)\end{array}$ & $\begin{array}{c}\text { Large companies } \\
(\%)\end{array}$ \\
\hline Food and drink industry & 99.1 & 0.9 \\
Bakery and farinaceous products & 99.6 & 0.4 \\
Oils and fats & 99.5 & 0.4 \\
Grain mill and starch products & 99.0 & 1.0 \\
Beverages & 98.8 & 1.2 \\
Animal feeds & 98.7 & 1.3 \\
Meat products & 98.6 & 1.4 \\
Various food products & 98.2 & 1.8 \\
Processed fruit and vegetables & 98.0 & 2.0 \\
Fish products & 97.9 & 2.1 \\
Dairy products & 97.7 & 2.3 \\
\hline
\end{tabular}

Source: FoodDrinkEurope (2014).

SMEs and micro-enterprises comprise 99.1 per cent of European food and drink businesses (Table 4.6). These companies generate 48.1 per cent of food and drink turnover, and employ 61.6 per cent of the food and drink workforce. In contrast, large companies account for just 0.9 per cent of all food and drink enterprises in Europe but provide 51.6 per cent of the turnover and 53.5 per cent of the value-added and contribute 38.4 per cent of the employment (FoodDrinkEurope, 2014). Small-scale enterprises by their size prevent the acquisition of economies of scale and make them impermeable to the introduction of innovations and of new products. There are few European multinational companies competing worldwide with a wide variety of products. In total, research and innovation expenditure is only 0.53 per cent of food and drink industry turnover.

During 2005-2015 the European F\&B industry has had relatively limited but stable growth in production and has maintained the characteristics of a non-cyclical and robust sector despite the economic crisis: production increased with 2.6 per cent growth between 2008 and 2011, compared to a 4.2 per cent decrease in the whole European manufacturing sector. However, labour productivity in the European food and drink industry is lower than in most other industries due to the high number of employees per company, the higher percentage of part-time employees and a generally lower percentage of employees with high-level skills (FoodDrinkEurope, 2014). 


\subsection{Asia}

According to the Asian Development Bank (ADB, 2009), the agricultural sector is important for all Asian countries: on average, more than 60 per cent of the working population depends on agricultural activities. If the incidence of agriculture in GDP decreases, this affects a significant part of the population who live in rural areas and, therefore, depend indirectly or indirectly (for employment or income) on the agricultural sector. Poverty is concentrated in rural areas, the disparity between rural and urban areas is widespread and the importance of agriculture varies from region to region. In some areas, agriculture and rural development are not means for economic development, but their importance, however, is in terms of food security. Over the years in Central Asia and East Asia the incidence of agriculture in gross domestic product (GDP) has decreased, even if a large percentage of workers are still employed in it. The main problem of the eastern Asian countries is land scarcity that drives some countries to land procurement (purchases or rentals) in other parts of the world. Also in Southeast Asia, the importance of the agricultural sector is shrinking, but to meet additional food requirements natural resources (land and water) have been hyper-exploited. As in Central and East Asia, agriculture in Southeast Asia is important as a source of employment. In this region, however, the share in the GDP contribution of the agricultural sector decreases more slowly. Generally speaking, agriculture is important for Asia to achieve food security and maintain employment. The systems of production and innovation and types of crops cultivated, however, vary from region to region, as well as the public support systems. The impact of climate change, finally, could in future erode productivity and, as a consequence, the ability to achieve food security. This vulnerability is especially feared in respect of rice and wheat, which are staple foodstuffs for the population (FAO, 2015). With a growing population, an increasingly accentuated price volatility of agricultural commodities and the unpredictable effects of climate change, the Asian continent has to face a number of challenges. In the 1970s, many Asian countries, thanks to the green revolution, became self-sufficient, but recent agricultural investments have tended to decrease or remain constant (Carrasco and Mukhopadhyay, 2012). By contrast, Asia is also the continent where biotech crops are very common (ADB, 2013) and this contributes to the global emissions from agriculture of 37 per cent of total global emissions (including 18 per cent of the total emissions from China). 


\section{FOOD SECTOR IN SELECTED ASIAN COUNTRIES}

Asia is an immense continent with a population of more than four billion people (2011) and a surface area of 32 million $\mathrm{km}^{2}$ incorporating conditions varying from moist tropical to arid and semi-arid desert. As would be expected by this geography, the human and social dimensions of the Asian continent are equally diverse (World Bank, 2015). As regard to agriculture, as shown in Table 4.7, agricultural land is 53.7 per cent and arable land 16.3 per cent of the total area. ${ }^{6}$ The Asian continent has a shortage, compared to population, in available land (values always lower than the world average figure) and water resources. In some of the selected Asian countries, namely Singapore, Taiwan, Korea, India, and Japan, this particular deficiency is pronounced, while a better situation characterizes, in relative terms, Malaysia, Indonesia and China. A dramatic shortage is noted in water resources (Table 4.7) and this is a common denominator in all the selected Asian countries.

Permanent crops per capita are higher than the world average in Malaysia and, if permanent crops are calculated as a percentage of agricultural land, Malaysia is followed by the Philippines, Indonesia and Vietnam. Values per capita in respect of meadows and pastures are generally very low, except for China. The other selected countries are far below the Asian and the world averages (Table 4.8).

With regard to the industrial and retail F\&B sector, the situation is extremely diversified and varies from country to country. Regional growth projections principally reflect the evolution of demand. According to the International Monetary Fund (IMF, 2015) in 2013, China is the second largest economy in the world. The same source forecasts that by 2018 China will be the world's largest economy measured in GDP. The population is increasing at a lower rate compared to the last two decades, with a fertility rate of 1.8 per female, which is lower than the replacement rate. China is facing increased urbanization; about 51.3 per cent of the population lives in urban areas and according to expectations by 2030 more than 70 per cent will be urbanized. According to Euromonitor International (2014a), in 2030 the population of China will reach 1.4 billion, an increase of 4.7 per cent from 2012. Falling birth rates and increasing life expectancy mean that the population is ageing rapidly. In 2030, the median age will be 47.1 years and China will have the largest number of people over 65 years in the world. Imbalances between the sexes will continue, with men aged 0-20 years accounting for 55.0 per cent of all 0-20 year olds in 2030, compared to 54.8 per cent in 2012. The demographic trend will have strong consequences on food needs and socio-economic aspects of life. To 


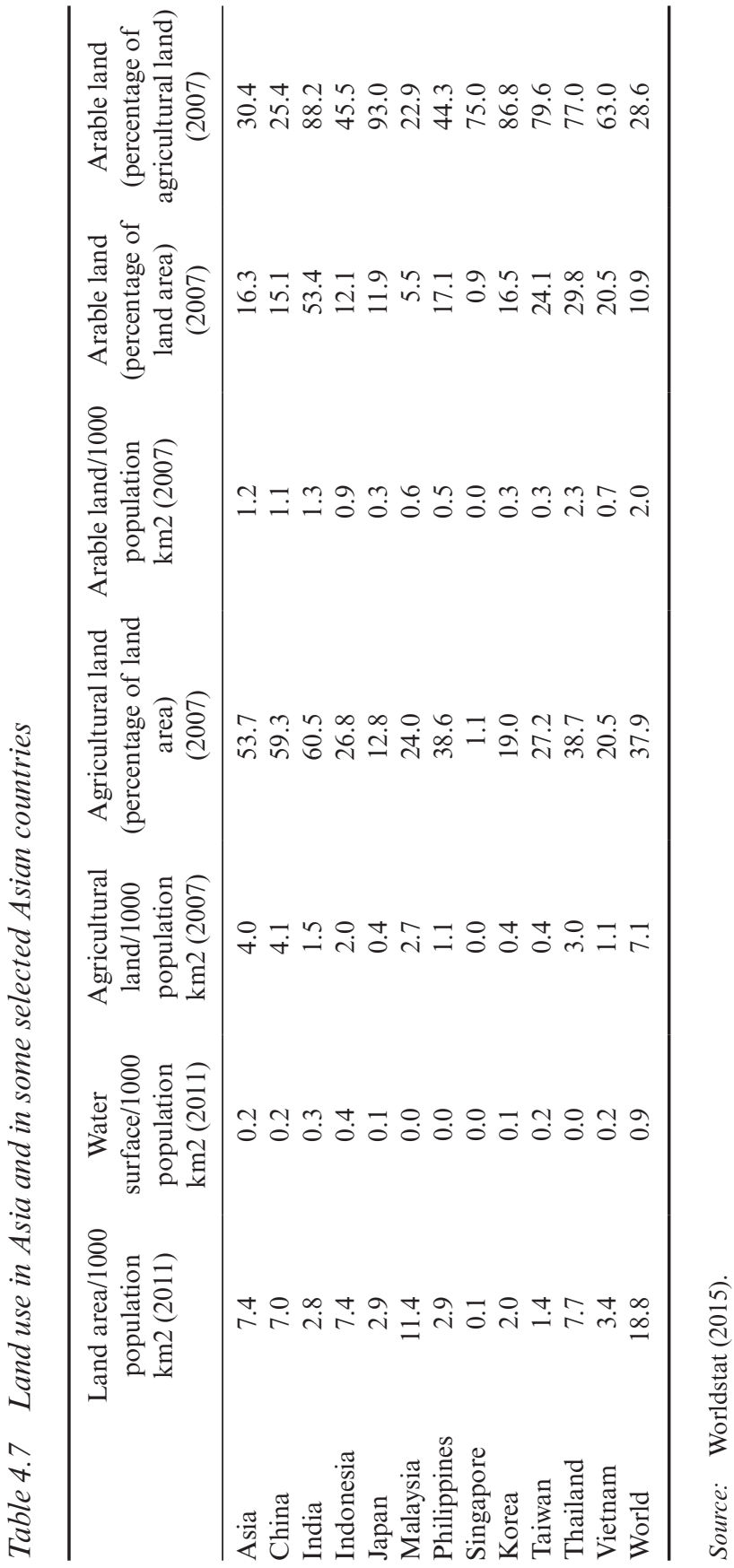


Table 4.8 Permanent crops and permanent meadows and pastures in Asia and selected Asian countries (2007)

\begin{tabular}{lcccc}
\hline & $\begin{array}{c}\text { Permanent } \\
\text { crops/1000 } \\
\text { population } \\
\text { km2 }\end{array}$ & $\begin{array}{c}\text { Permanent crops } \\
\text { (percentage of } \\
\text { agricultural land) }\end{array}$ & $\begin{array}{c}\text { Permanent meadows } \\
\text { and pastures/1000 } \\
\text { population } \\
\text { km2 }\end{array}$ & $\begin{array}{c}\text { Permanent meadows } \\
\text { and pastures } \\
\text { (percentage of } \\
\text { agricultural land) }\end{array}$ \\
\hline Asia & 0.2 & 4.1 & 2.6 & 65.5 \\
China & 0.1 & 2.2 & 3.0 & 72.4 \\
India & 0.1 & 6.0 & 0.1 & 5.8 \\
Indonesia & 0.6 & 32.0 & 0.4 & 22.7 \\
Japan & 0.0 & 7.0 & 0.0 & 0.0 \\
Malaysia & 2.0 & 73.5 & 0.1 & 3.6 \\
Philippines & 0.5 & 42.6 & 0.1 & 13.3 \\
Singapore & 0.0 & 25.0 & 0.0 & 0.0 \\
Korea & 0.0 & 10.1 & 0.0 & 3.2 \\
Taiwan & 0.0 & 3.6 & 0.1 & 5.1 \\
Thailand & 0.6 & 19.0 & 0.1 & 4.1 \\
Vietnam & 0.3 & 30.6 & 0.1 & 6.4 \\
World & 0.2 & 2.9 & 4.9 & 68.5 \\
\hline
\end{tabular}

Source: Worldstat (2015).

improve the quality of life, the demand for food will increase and this will be met by increasing imports. In this way, China attracts an increasing number of foreign businesses and to this end a number of bilateral agreements with neighbouring countries have been signed. The competition for the conquest of the Chinese market occurs mainly in two directions: commodity-type products (such as frozen meat, poultry meat, fish, fresh fruit) and Western-style niche products (olive oil, pasta, tomato sauce, wine). Export competition takes place among the Pacific countries (including New Zealand and Australia) for commodity-type products. For Western-style foods, the competition is more global. The trend of food consumption, however, is differentiated according to geographical location. In eastern China the demand is for healthy products and is very close to the Western style (in Shanghai, especially). Mid-China is more conservative and shows little interest in imported products. In the Chinese north and northeast, consumers demand high-quality products and proper packaging and food is perceived as wellness (products containing information on ingredients, expiration date, origin of raw materials and so on are preferred). The southwest is influenced by its geographical location, close to the sea, and consumers demand packaged dry or fresh fish and ice cream. Internet retailing is expanding from books to food and from electronics to cosmetics. Even conventional retailers are acquiring online shopping tools 
and the industry is expecting increased demand. The consumption of food outside the home is growing, thereby increasing demand for food with high value-added. Food consumption patterns are becoming more flexible and informal primarily among young and high-income urban consumers. For many Chinese, dinner outside the home has become a way of establishing and strengthening relationships both professional and personal. Restaurants offering imported products of high quality, a friendly environment and fast service are particularly attractive. Multinational companies operating in China have changed the flavour of food by introducing Chinese and Asian flavours and menus aimed at meeting the diverse local demands. The Chinese food industry showed significant changes in 20112012. Even though the food industry had achieved record sales, at the end of 2012 a slowdown occurred. In addition, the increasingly frequent incidents of adulteration have undermined consumer confidence. From 2012, the reduction in the growth rate is the result of the combined action of several factors: higher cost of ingredients, increased labour costs and production costs, higher costs of entry for new businesses, and financial problems for small companies. In response to these trends, many food companies have adopted new strategies such as product innovations inspired by Western styles, processes and business organization innovations. The Indian population in 2013 was about 1252 billion (World Bank, 2014). India has one of the youngest populations globally, with the country's average age being just under 29 years in 2014. A growing number of these young Indians have higher disposable incomes compared to their older counterparts. They also have a lower propensity to save (Euromonitor International, 2014b). Unlike China, the Indian fertility rate is higher than that of the replacement rate. As an emerging country, India is a very interesting place in terms of food consumption. Whilst staples such as dairy, baked goods, and oils and fats account for the largest proportion of packaged food sales in India, the bulk of the growth is set to come from impulse/indulgence products such as confectionery, ice cream, and sweet and savoury snacks. These products are growing very quickly in India. To protect domestic production, the Indian government has placed high tariffs and bans on imported products. However, rising incomes, increased urbanization and the availability of cheap credit presage a market in continuous and rapid expansion. India is a major producer of agricultural products and a net exporter of food. India is one of the world's largest producers of fruits, vegetables, cereals and milk. Domestic production takes advantage of low labour costs, ease of access to raw materials and the high level of protection provided by tariffs and duties imposed on imported products. Multinational companies have opted for investment and production in India rather than export to India. As a result, a significant number 
of international companies develop products in India and these are marketed as Indian products. The restaurant sector in India is not yet fully developed. Young Indians tend more frequently to have meals outside the home, going against the prejudice of adult classes against foreign and international food. The Indian food industry continues to expand in response to demographic changes. It is, however, a small expansion in percentage terms. Only a small portion of agricultural products is processed. The problem relates to Indian food losses due to lack of infrastructure such as storage facilities and transport. Indonesia, a food importing country, is the fourth most populous country in the world with 249.9 million inhabitants in 2014, according to the World Bank (2015). The population is ageing rapidly and the number of those aged $50+$ will increase by 84 per cent between 2012-2030, according to Euromonitor estimates (Euromonitor International 2013a), while the number of children aged 0-9 years will decline by 14.6 per cent. In 2030, Jakarta, the capital, will continue to dominate the urban landscape with a population of 13.7 million. According to forecasts, by 2030 the middle classes will be 80 per cent of the population (Euromonitor International, 2013a). Indonesia is the most stable democracy in Southeast Asia. Despite the extremely positive trend of the Indonesian economy, a significant part of the population is low-income, infrastructure is poorly developed and imports are subject to complex rules. This means that any foreign company needs a local agent. Labels, written in Indonesian, must be attached to products before entering the Indonesian market. The prices of imported products are generally higher than those domestically produced. Hypermarkets, supermarkets and minimarkets are growing and are in direct competition with local sellers for price, cleanliness, comfort and health standards. The Western style is common in large cities, but variety is limited. Restaurants which offer noodles, pizza and Japanese food, as well as bakeries and cafes, are the main outlet of the Western-style food supply and depend on imports. Indonesian ties with Europe are strong and they influence domestic consumer preferences. Japan will be in the midst of a demographic crisis between 2012-2030 as it is experiencing depopulation and ageing. According to Euromonitor International (2013b), in 2030 nearly one-third of the population will be aged $65+$ and the median age of the population will continue to be the highest in the world. Net migration, although positive, will not be able to mitigate the effects of ageing or depopulation. The (albeit weak) GDP growth in real terms of the Japanese economy in recent years has been driven by consumption, especially public expenditure. Investments, by contrast, have played a marginal role and energy concerns accentuated after the disaster of Fukushima led to a slowdown in the growth rate. The population is decreasing and the average age 
is higher compared with that recorded by other Asian countries. Japan is a net importer of agricultural products and food, due to limited arable land (Table 4.7). The demand for products with high value-added is growing and this makes the market attractive to multinationals. Generally, the Japanese consumer is willing to pay a higher price for a higher-quality product, but the reducing rate of growth has brought greater attention to prices, compared to the past. As previously mentioned, the Japanese market is a saturated market and thus some supermarkets have closed and, to face the new challenge based on pricing, the distribution system has been focusing on controlling costs and improving efficiency. An important part of food expenditure is for meals away from home. Dinners outside the home are part of Japanese culture: one food category which continues to post growth rates is meals sold in retail stores. Young and old single professionals influence the trend of meals away from home. While older people buy ready-to-eat meals in the local 'conbini' (local convenience store), young professionals, by contrast, prefer Western-style restaurants. The key drivers of the food processing sector are more women in the workforce, an ageing population and health conscious consumers (OECD, 2001). Thus, the Japanese food processing industry remains a vibrant market. The food processing industry is rather concentrated in Japan. A total of 15 companies have a market share of around 50 per cent of sales. The United States is the largest exporter of agricultural products to Japan. The greatest agricultural competitor to the United States is China, whose exports are growing. According to Euromonitor International (2014c), the population of Malaysia will reach 36.0 million in 2030, an increase of 22.6 per cent from 2012. Population growth has been slowing since the 1980s and this trend will continue between 2012-2030 due to a fall in fertility rates and in lower flows of net immigration. Despite the rapid growth of the $60+$ age group between 2012-2030, the population will remain relatively young with three-quarters of the population aged under 50 by 2030 . Malaysia is a politically and economically stable country, open to trade and with good transport and communications systems. Infrastructure is generally modern and efficient. In Southeast Asia it is the most developed country, with 61 per cent of the population falling into the medium-high income category. Even if Malaysia is a net importer of food, the food supply sector is well developed and sophisticated, thanks to domestic production and imports. Even with high productivity, Malaysia still only produces 80 per cent of what it needs to support itself and thus must import the rest, while food demand continues to grow due to improved incomes. China is the largest exporter of food to Malaysia, followed by India and New Zealand. A total of 60 per cent of the population are Muslims, therefore only halal meat can enter the country. Further, before being sold, 
imported products must be approved by the Malaysian Islamic Development Department. The Islamic food certification involves meat and other products, such as snacks, confectionery, dairy foods, bakery products, and so on. The government of Malaysia has identified the processed food sector as one of the strategic sectors. Despite being an importing country there are approximately 3200 Malaysian companies operating in the food industry, with a turnover of about 10 per cent for manufacturing as a whole. The main exported products (to more than 200 countries) are cocoa and processed cocoa, vegetable margarines and vegetable preparations. Operating in Malaysia are not only local companies but also large multinationals such as Nestle, Unilever and Campbell's. Hypermarkets are the retail formula most prevalent in urban areas, while the traditional markets are losing ground; however, small shops selling fresh fruit and vegetables are still widespread. By 2030, the population of the Philippines will reach nearly 128 million, an increase of 32.1 per cent from 2012. Population growth will be driven by increases in all age groups with a particularly fast growth in the $60+$ age groups. However, according to forecasts (Euromonitor International, 2013c) the Philippines will remain an overwhelmingly young country by 2030 , with 71.4 per cent of the population aged 40 years or under. The urban population will overtake the rural population for the first time in 2016 and will comprise, by 2030, 56.3 per cent of the population. The economy of the Philippines is growing as a result of domestic demand and the efforts of rebuilding after Typhoon Haiyan in 2013. The United States is the largest exporter of agricultural products, especially processed food. Recently, other actors such as New Zealand, Australia, the EU, Canada and ASEAN countries have entered the market. It should be noted that China has obtained through aggressive marketing significant segments of the import market, especially for fresh fruit and dry goods. There are approximately 11000 businesses operating in the food sector, with an extremely varied range of products. These companies depend on imported ingredients from abroad. Despite the prevalence, in the sector, of multinational companies, local businesses are family owned and hold a significant portion of the market. The processed food sector is the largest sector of the economy of the Philippines with a turnover of about 40 per cent of the total manufacturing sector and a contribution to GDP of around 20 per cent. The retail sector, dominated by multinationals, is undergoing modernization and expansion. By 2030 the population of Singapore is expected to reach 6.9 million, an increase of 30.8 per cent from 2012: net migration will account for over three-quarters of this growth. The number of live births will increase because of rising fertility, while the number of deaths will rise due to increases in older population groups. Singapore is a city-state and had the fourth highest population 
density in the world in 2012 at 7589 persons per square kilometre (Euromonitor International, 2013d). Singapore is one of the most open and competitive markets in the world. The economy depends on exports especially in the services sector. Its high per capita income places Singapore as Asia's richest nation. Its geographical position ensures its central distribution role (by sea, land and air) of products for the major regions of Southeast Asia and the Indian sub-continent. It is a food importing country and the demand for food must meet both the local population's and the foreign population's (generally tourism) food needs. The food industry of Singapore is extremely limited, because the country does not produce agricultural raw materials and all ingredients have to be imported. According to the statistics of the government of Singapore (Department of Statistics of Singapore, 2015) there are about 300 companies operating in the agro-food sector, all of which range from small to medium in size. Imported food origins vary from product to product: dairy products come mainly from Australia, cereals from China, and fruit and fruit processing from the United States. South Korea is known for its population density, which is more than ten times the global average. Due to rapid migration from rural areas as a result of the quick economic expansion since the 1970s, South Korea is now Asia's fourth largest economy. The population is now being shaped by international immigration. This trend of net entry reverses over 40 years of emigration (World Population Review, 2015). The population of Korea is gradually ageing and one-child families are increasing. To limit concerns on public expenditure to support the retirement of older people, the entry of women into the working world is being facilitated. Korean food consumption patterns reflect its demographic changes, its increasing urbanization and the adoption of new technologies (namely online shopping). Korea is a food importing country and the government protects local food industries and farmers by imposing constraints on food imports such as high tariffs, quotas and high phytosanitary standards. But, in order to reduce barriers to imports to ensure food security, many regional free trade agreements have been signed (Zolin and AndreossoO'Callaghan, 2013). Large-scale stores dominate small retail stores. Some social initiatives are pressing the government to introduce limits to the expansion of large-scale stores in order to protect jobs and enable small businesses to survive. Taiwan's population of about 23 million in 2014 (World Bank, 2015) is showing a fast and progressive ageing trend reflecting low fertility rates. Despite being an economic power, domestic agricultural production is limited. As a result, imports of food and agricultural products increase annually. The globalization of markets and the growing consumer demand for new and different varieties makes Taiwan extremely attractive for food and raw materials' exporters of agricultural origin. 
Food is sold mainly in convenience stores (Taiwan has the highest density of convenience stores in the world), although hypermarkets and supermarkets count for a good share of the consumer market. Western foodstuffs are popular; in particular, Italian foodstuffs. Increased tourism has driven the growth of restaurants and hotels. Processed food increases can also be attributed to rises in average per capita income, women's entry into the workplace, small families (single child), and the development of online shopping. The food processing industry has benefited from the market opening up. At the same time, imported finished food products have been taking an increased market share from domestically produced products and this trend is expected to continue. The Thai food processing industry has benefited from the opening up of food markets, but import duties are very high even for products that are not competitive with domestic products. Many multinational companies prefer to produce locally, or in neighbouring countries with which Thailand has signed free trade agreements rather than import. The problem with the Thai economy is the shortage of labour, which is resolved by immigration of workers from Burma. If these workers should ever return to Burma, the problem of labour nonavailability would significantly affect the industry. The demand for packaged food is growing and Thailand is, from this point of view, the most interesting market in the Asia-Pacific region. This growth has attracted foreign investors, especially Europeans. The food service sector is driven by tourism. Sidewalk restaurants are gradually being replaced by food centres and food courts, which are more hygienic and convenient. The food processing industry is one of the most developed in Southeast Asia and Thailand is one of the largest manufacturers of a wide variety of agricultural commodities such as rice, rubber, cassava, sugar, seafood, processed fruits and vegetables. Company sizes range from small to medium to large. SMEs are oriented to the domestic market, while the medium-sized enterprises also produce, generally, high-value-added products destined for both the domestic market and export. About 50 per cent of domestic production is exported. A young population, growing middle-class incomes and high labour participation by women drive the trend of consumption in Vietnam. Despite positive demographic trends, the fertility rate is decreasing and has fallen to a level below replacement level and below the Asian average. There is also a movement of population from rural to urban areas. These factors help to shape the demand for food, especially ready-to-eat meals. The packaged food sector has experienced and is experiencing high growth rates. Even if traditional fresh food markets and small independent shops catering to high-frequency food purchases dominate the retail market, hypermarkets and supermarkets are widespread in urban areas. Local importers continue to play a decisive role in the introduction and 
marketing of imported food products. The food service sector is affected not only by the dynamics of income and population growth, but also by tourist flows, with the diffusion of Western consumption patterns. Competition among local companies has intensified with the entry of multinationals and some local operators are diversifying their production by following a strategy of Westernization. With regulations that are more transparent, the Vietnamese government has managed to attract foreign investment and to intensify internal investments. The government also protects local production by imposing higher customs rates on imports the greater the competition between imports and domestic products.

\section{CONCLUDING REMARKS}

What emerges from the analysis is that in the long term an impressive number of factors will affect Asian food supply and demand. In Asian countries, food demand is generally expected to increase, with the exception of some developed countries (Japan), because of demographic changes. The increasing population pushing up food requirements in some regions could aggravate the risks of food shortages. Economic growth, rising incomes and urbanization may also contribute to the expected surge in food demand, not least via rapid changes in diets in favour of more grain-intensive foods such as meat, and in particular red meat. In respect of population forecasts, a variety of factors, including enhanced family planning and reduction of poverty, could lead to lower demographic growth, and thus to a lower increase in food demand. However, for a given level of national income, a more uneven income distribution among the population might also weaken food demand. This could be the case of China where, in 2012, for the first time, China's urban population surpassed that of rural areas (World Bank, 2015). Moreover, the evolution of consumer tastes and diets may gain in importance at the expense of the traditional determinants of demand. For instance, growing safety and ecological concerns may lead to a sustained demand for products with certain organic attributes ('semiorganic' produce). In the developed countries, like in European countries, or Japan, on the other hand, per capita food demand could gradually level off, and consumption is likely to change much more in composition and quality than in volume over the next two decades. On the supply side, the availability of land, water and other natural resources emerges as a matter of major concern. Water resources, which have been affected by intensive use of fertilizers and pesticides and by excessive pumping, are becoming scarce in many parts of the world, inhibiting the development of irrigation. In relation to land, it is generally acknowledged that the net expansion of 
cultivated areas will be modest in the future, not least due to urbanization and the need to preserve forests. Climate change effects emphasize that the risk of land losses due to erosion, salinization, water logging or contamination may actually outweigh new lands brought into cultivation. Another major source of uncertainty is the evolution of productivity that still offers the potential for major improvements in food production, most notably in developing Asian countries. It is generally agreed that food supply will be highly responsive to price signals in the two next decades. An increase in world prices would trigger intensification in production and the use of reserves of land, but local imbalances cannot be excluded. For some less developed Asian countries and transition economies, the necessary market infrastructure (transport, processing, marketing and storage) is still poorly developed. Constraints on natural resources could limit the agricultural capacity of specific countries where demand is expected to surge, thus increasing their net imports. Some analysts, for instance, underline the risk of agricultural supply in China being handicapped by substantial land losses due, in particular, to urbanization, and a weakening of productivity gains linked to insufficient investment in agricultural research. The Asian continent is facing some pressure on resources in respect of its food needs, and the main challenges are related to:

1. ensuring the matching of supply and demand for food without compromising resources for future generations;

2. reducing poverty and vulnerability of the poorer part of the population, protecting against price fluctuations and providing adequate social security;

3. improving the food chain, aiming at providing sufficient and safe food;

4. creating a system and tools of risk management in terms of food safety and food reserve stocks for emergencies including natural and technological disasters.

According to the Asian Development Bank (2013), the Asian continent, in relation to food security and food safety, has two faces. Economic growth continues to influence the demand for more protein-rich food and better nutrition. Calories per capita per day on average have increased, but a significant share of the population lives in poverty and suffers from undernourishment. 


\section{NOTES}

1. BMI (Body Mass Index) is the calculation of the ratio between weight and height, usually used as a simple tool to estimate fatness.

2. The World Food Summit of 1996 defined food security as existing 'when all people at all times have access to sufficient, safe, nutritious food to maintain a healthy and active life'. Commonly, the concept of food security includes both physical and economic access to food that meets people's dietary needs as well as their food preferences. In many countries, health problems related to dietary excess are an ever increasing threat, In fact, malnutrition and food-borne diarrhoea are becoming double burdens. Food security is built on three pillars: food availability - sufficient quantities of food available on a consistent basis; food access - having sufficient resources to obtain appropriate foods for a nutritious diet; and food use - appropriate use based on knowledge of basic nutrition and care, as well as adequate water and sanitation (FAO, 1996, p.4).

3. With more than four million persons employed and an annual turnover in excess of EUR900 billion.

4. In terms of utilized agricultural area.

5. In the reforms made in 2013 for the period 2014 to 2020 , each country can choose if the payment is established at the farm level or at the regional level. Farmers receiving the SFP have the flexibility to produce any commodity on their land except fruit, vegetables and table potatoes, but they have to keep their land in good agricultural and environmental condition (cross-compliance). If farmers do not respect these standards, their payment will be reduced.

6. The FAOSTAT glossary defines agricultural land or agricultural area as the total of: arable land (describing land producing crops requiring annual replanting or fallow land or pasture used for such crops within any five-year period), permanent cropland (land producing crops which do not require annual replanting) and permanent pasture (natural or artificial grassland able to be used for grazing livestock). Permanent cropland includes forested plantations used to harvest coffee, rubber or fruit but not tree farms or proper forests used for wood or timber (FAOSTAT, 2014).

\section{REFERENCES}

Asian Development Bank (ADB) (2013), 'Food Security in Asia and the Pacific', Manila: Asian Development Bank.

Asian Development Bank-International Food Policy Research Institute (2009), 'Building Climate Resilience in the Agriculture Sector in Asia and the Pacific', Manila: Asian Development Bank.

Carrasco, B. and Mukhopadhyay, H. (2012), 'Food Price Escalation in South Asia: A Serious and Growing Concern', ADB Working Paper Series No. 10, February.

Department of Statistics of Singapore (2015), 'Latest Key Indicators', available at http://www.singstat.gov.sg/.

Euromonitor International (2013a), 'Indonesia in 2030: The Future Demographic', available at http://www.euromonitor.com/indonesia-in2030-the-future-demographic/report.

Euromonitor International (2013b), 'Japan in 2030: The Future Demographic', available at http://www.euromonitor.com/japan-in-2030-the-future-demographic/ report.

Euromonitor International (2013c), 'Philippines in 2030: The Future Demographic', available at http://www.euromonitor.com/philippines-in-2030the-future-demographic/report. 
Euromonitor International (2013d), 'Singapore in 2030: The Future Demographic', available at http://www.euromonitor.com/singapore-in-2030-the-future-demo graphic/report.

Euromonitor International (2014a), 'China in 2030: The Future Demographic', available at http://www.euromonitor.com/china-in-2030-the-future-demographic/ report.

Euromonitor International (2014b), 'Food Trends in India: What Makes the Indian Market so Different?', October, available at http://www.euromonitor. com/food-trends-in-india-what-makes-the-indian-market-so-different-/report.

Euromonitor International (2014c), 'Malaysia in 2030: The Future Demographic', available at http://www.euromonitor.com/malaysia-in-2030-the-future-demo graphic/report.

European Commission (2013a), 'Structure and Dynamics of EU Farms: Changes, Trends and Policy Relevance', EU Agricultural Economics Briefs, No. 9, October.

European Commission, Directorate General for Agriculture and Rural Development (2013b), 'Agriculture in the European Union: Statistical and Economic Information', available at http://ec.europa.eu/agriculture/statistics/ agricultural/2013/index_en.htm.

European Commission, Enterprise and Industry (2015), 'Raising the Bar for Europe's Food Industry', available at http://ec.europa.eu/growth/sectors/food/.

FAO (1996), 'World Food Summit', 13-17 November 1996, Rome, available at http://www.fao.org/docrep/003/w3613e/w3613e00.htm.

FAO (2012), 'The State of Food Insecurity in the World', Food and Agriculture Organization of the United Nations, Rome, available at http://www.fao.org/ docrep/016/i3027e/i3027e.pdf.

FAO (2014a), 'Country Profile', available at http://www.fao.org/countryprofiles/ en/.

FAO (2014b), 'The State of Food Insecurity in the World', Food and Agriculture Organization of the United Nations, Rome, available at http://www.fao.org/3/a-i4030e.pdf.

FAO (2015), 'The State of Food Insecurity in the World', Food and Agriculture Organization of the United Nations, Rome, available at http://www.fao.org/3/ a4ef2d16-70a7-460a-a9ac-2a65a533269a/i4646e.pdf.

FAOSTAT (2014), available at http://faostat.fao.org/site/375/default.aspx.

FoodDrinkEurope (2014), 'Data \& Trends of the European Food and Drink Industry 2013-2014', Brussels, available at http://www.fooddrinkeurope.eu/S=0/ publication/data-trends-of-the-european-food-and-drink-industry-2013-2014/ http://www.fooddrinkeurope.eu/uploads/publications_documents/Data_ Trends_\%28interactive $\% 29 . p d f$.

ILO (2012), 'Food, Drink and Tobacco Industry Driving Rural Employment and Development', available at http://www.ilo.org/wcmsp5/groups/public/---ed_ dialogue/---sector/documents/publication/wcms_160872.pdf.

IMAP (2010), 'Food and Beverage Industry Global Report', available at http:// www.imap.com/imap/media/resources/IMAP_Food_Beverage_Report_WEB_ AD6498A02CAF4.pdf.

IMF (2015), 'World Economic Outlook - Uneven Growth: Short- and Long-Term Factors', April, Washington DC, available at http://www.imf.org/external/pubs/ $\mathrm{ft} /$ weo/2015/01/pdf/text.pdf.

OECD (2001), 'Working Party on National Environmental Policy. Sustainable 
Consumption, Sector Case Study Series - Household Food Consumption Trends, Environmental Impacts and Policy Responses', Environment Directorate, 14 December, available at http://www.oecd.org/officialdocuments/ publicdisplaydocumentpdf/?cote=ENV/EPOC/WPNEP $\% 282001 \% 2913 /$ FINAL\&docLanguage $=$ En .

Oxfam (2013), 'Behind the Brands - Food Justice and the "Big 10" Food and Beverage Companies', 26 February, Oxfam Briefing Paper No. 166, available at http://www.oxfam.de/sites/www.oxfam.de/files/studie_behind_the_ brands_260213.pdf.

USDA (2013), 'Chart: Food Manufacturing Accounts for 14 Percent of all U.S. Manufacturing Employees', United States Department of Agriculture, Economic Research Service using data from US Census Bureau Annual Survey of Manufactures 2013, available at http://ers.usda.gov/data-products/chart-gallery/ detail.aspx?chartId=40045\&ref $=$ collection\&embed=True\&widget Id $=39734$.

WHO (2014), 'Global and Regional Food Consumption Patterns and Trends', available at http://www.who.int/nutrition/topics/3_foodconsumption/en/index3. html.

World Bank (2014), 'India Development Update: Towards a Higher Growth Path', India development update, Washington DC, World Bank Group, available at http://www-wds.worldbank.org/external/default/WDSContentServer/ WDSP/IB/2015/04/27/090224b082e11f0f/1_0/Rendered/PDF/

India0developm0a0higher0growth0path.pdf.

World Bank (2015), 'Database', available at http://data.worldbank.org/indicator.

World Population Review (2015), 'Country Populations 2015', available at http:// worldpopulationreview.com/countries/.

WorldStat (2015), 'WorldStat Info', available at http://www.wboxi.com/site/worldstat.info.

Zolin, M.B. and Andreosso-O'Callaghan, B. (2013), 'The Korea-EU FTA: New Prospects for and Patterns of Agricultural and Agrifood Trade?', Journal of Global Policy and Governance, 1 (2), 129-142. 
